\title{
FINANCIAL LITERACY, MATHEMATICS LITERACY AND ATTITUDE TOWARDS THE USE OF FINTECH SMARTPHONE APPS: A CASE STUDY OF INTERNATIONAL COLLEGE, SUAN SUNANDHA RAJABHAT UNIVERSITY
}

\author{
Krongthong Khairiree
}

Suan Sunandha Rajabhat University, Bangkok, Thailand

The purposes of this study have been to explore financial literacy, mathematics literacy, and also the attitude towards the use of fintech smartphone apps among the students and alumni of the International College, Suan Sunandha Rajabhat University (Bangkok, Thailand). The stratified random sampling was employed in this study on the sample consisting of 273 units. The research finding reveal that $72.6 \%$ of the respondents possess the moderate level of knowledge and skills in financial literacy and in mathematics, while $4.5 \%$ of them have such skills at high level and $20.4 \%$ - at low level. The attitude among the students and alumni of the International College towards the use of fintech smartphone applications was divided into five areas. These were the ability and limitation, accuracy, safety, convenience and worthiness. The research findings reveal that the attitudes among the surveyed students and alumni were not much different. This was, most probably, because the sample units were in the same group of the generation Y (16-35 y.o.). This age group is using smartphones all the time and they are well familiar with many applications, including fintech ones. The research findings and conclusions can be used as guidelines while developing finance-related curriculum and also in mathematics learning instructions which may involve fintech apps use.

Keywords: financial literacy, mathematic models, application, education

\section{Introduction}

The Government of Thailand is now taking steps to move the country towards a new economic model "Thailand 4.0". Thailand 4.0 focuses on a value-based economy, as the country needs to deal effectively with disparities and the imbalance between the environment and the society. One of the Thailand 4.0 elements is knowledge-based economy with the emphasis on research and development, science and technology, creative thinking and innovation.

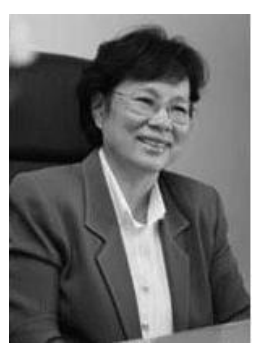

\section{Krongthong Khairiree}

Ph.D. (Mathematics Education), assoc. professor, dean of International college Suan Sunandha Rajabhat University, Bangkok, Thailand

Executive Board Member of NIETS (National Institute of Educational Service (Public Organization)

Research interests: math modeling, financial literacy, educational management.

E-mail: krongthong.kh@ssru.ac.th 


\section{FINANCIAL LITERACY, MATHEMATICS LITERACY}

OECD is an acronym for the Organization for Economic Cooperation and Development. OECD was established as an inter-government project back in 1961. Today, one of its top priority purposes is to improve financial education and literacy standards through the development of common financial literacy principles. OECD had an assessment program to evaluate educational systems in both member or non-member countries. This assessment program is known as PISA, or the Programme for International Student Assessment. PISA assesses 15-year-old school students' performance in mathematics, science and reading. The assessments are repeated every three years. In 2012, PISA assessed another level of knowledge among the students, namely, financial literacy.

\section{Financial literacy}

Financial literacy is defined as a combination of awareness, knowledge, skills, attitudes and behavior necessary to make sound financial decisions and ultimately achieve individual financial well-being (Atkinson \& Messey, 2012). According to the OECD (2017), financial literacy covers knowledge and understanding of the financial concepts and skills, motivation and confidence to apply such knowledge and understanding in order to make effective decisions across a range of financial context, to improve the financial well-being of individuals and society, and to enable participation in economic life. Financial literacy also means possession of a certain set of skills and knowledge that allows individuals make informed and effective decisions with all of their financial resources (OECD, 2017). According to PISA results, students who do well in financial literacy are likely to perform well in other areas too, and students who have poor financial literacy skills are likely to do poorly in other subjects. PISA test results reflect strengths and weaknesses of each national educational system and may serve as a guideline for future improvement across the countries OECD/INFE (2011).

Back in 2015, the OECD conducted the International Survey of Adult Financial Literacy. 51,650 adults from 30 countries participated in this survey. Thailand participated in this survey too. This survey finding provided high-level highlights focusing on financial knowledge, attitudes and inclusion, and also insights into the financial literacy of population and their needs in terms of education and other forms of support. The survey results demonstrated that "Overall levels of financial literacy indicated by combining scores on knowledge, attitudes and behavior are relatively low". The average score across all the participating countries was 13.2 (out of 21 maximum), and Thailand obtained only 12.8 (OECD/INFE, 2016).

The results of the Students' Financial Literacy 2015 revealed that both developed and emerging countries have become increasingly concerned about the level of financial literacy among their citizens and particularly among young people. Many young people today are facing financial decisions as they are consumers of financial services. Financial literacy is now globally recognized as an essential life skill and an essential element in the education of critical and responsible citizens. Thailand has a lot to learn from the OECD-PISA Students Financial Literacy Survey 2015 results and findings.

This is because PISA examines not just what students know in science, reading and mathematics, but what they can do with that knowledge and the skills they have (Khairiree, 2018). The results obtained by PISA show educators and policy makers the quality and the equity of learning outcomes achieved elsewhere, thus, they allow policy makers learn from 
the policies and practices applied in other countries. This survey also explores students' experience with and knowledge about money and provides an overall picture of the 15 -yearolds' ability to apply their accumulated knowledge and skills to real-life situations involving financial issues and decisions (OECD, 2017).

\section{SSRUIC: Financial Literacy and Mathematics Literacy Survey}

The International College of the Suan Sunandha Rajabhat University (SSRUIC) in Bangkok, Thailand, has conducted its own survey research on financial literacy, mathematics literacy and financial attitudes. The participants were the current students and the alumni of SSRUIC. The stratified random sampling was employed in this study and the sample consisted of 233 units, $35 \%$ being male and $65 \%$ - female.

Table 1- Contents of the SSRUIC 2019 Questionnaire

(made by author)

\begin{tabular}{|c|c|c|}
\hline \multicolumn{3}{|c|}{ Financial Literacy } \\
\hline Financial Knowledge & Financial Behavior & Financial Attitude \\
\hline $\begin{array}{l}\text { 1. Division: Calculation } \\
\text { of mean }\end{array}$ & 1. Considered purchase & $\begin{array}{l}\text { 1. I find it more satisfying to } \\
\text { spend money than to save it for } \\
\text { the future. }\end{array}$ \\
\hline 2. Calculation of interest & 2. Saving plan & $\begin{array}{l}\text { 2. I save money on a bank } \\
\text { account. }\end{array}$ \\
\hline $\begin{array}{ll}\text { 3. } & \text { Calculation of } \\
\text { principle plus interest }\end{array}$ & $\begin{array}{l}\text { 3. Thinking before making a } \\
\text { purchase }\end{array}$ & $\begin{array}{l}\text { 3. I have a long-term financial } \\
\text { goal, and I try to achieve my }\end{array}$ \\
\hline $\begin{array}{l}\text { 4. Calculation of } \\
\text { compound interest }\end{array}$ & 4. Paying bills on time & goal. \\
\hline 5. Inflation money & $\begin{array}{l}\text { 5. Keeping watch on } \\
\text { financial affairs }\end{array}$ & \\
\hline 6. Time value money & $\begin{array}{l}\text { 6. Long-term financial goal } \\
\text { setting }\end{array}$ & \\
\hline
\end{tabular}

The questionnaire consisted of three parts, namely: 1) Financial knowledge; 2) Financial behavior; and 3) Financial attitude.

Financial knowledge is an important component of financial literacy for all persons, as it helps them compare financial products and thus make more well-informed financial decisions. Basic knowledge of the core financial concepts and the ability to apply numeracy skills in a financial context may have profound implications for people's financial wellbeing.

Financial behavior means people' actions towards various financial issues, such as saving, spending, and budgeting money. The OECD/INFE (2015) described that some types of behavior may impact negatively on an individual's financial situation and well-being, such as putting off bill payments, failing to plan future expenditures or choosing financial products without shopping around.

Financial attitude refers to individual beliefs and feelings that take the form of tendencies towards certain financial practices and/or actions. Even though people may 
possess sufficient knowledge and skills in a certain area, their attitudes may have more influence on their further decisions and actions. Thus, financial attitude is deemed as an important element of financial literacy, given that individual preferences are the determinants of financial behavior (OECD, 2017).

Table 2 - Criteria, mean and standard deviation for financial literacy and mathematics literacy in the sample group

(made by author)

\begin{tabular}{|c|c|c|c|}
\hline Criteria & Levels & Interval Scores & $\begin{array}{c}\text { \% of the } \\
\text { respondents }\end{array}$ \\
\hline $\mathrm{X}<(\underline{x}-2 S D)$ & Lowest & $<3.75$ & 0.0 \\
\hline$\underline{x}-2 S D<x<\underline{x}-S D$ & Low & $3.75-7.20$ & 20.4 \\
\hline$\underline{x}-S D<x<\underline{x}+S D$ & Middle & $7.21-14.10$ & 72.6 \\
\hline$\underline{x}+S D<x<\underline{x}+2 S D$ & High & $14.11-17.55$ & 2.3 \\
\hline $\mathrm{x}>(\underline{x}+2 S D)$ & Highest & $>17.55$ & 4.5 \\
\hline
\end{tabular}

The financial literacy scores of the participants were classified into five levels based on the mean and standard deviation scores. As it is demonstrated in Table 2, the results reveal that the mean and the standard deviation values of financial literacy in the sample group are 10.65 and SD 3.45 (the total score is 20 ). The absolute majority (72.6\%) of the respondents belong to the mid-level group and the highest group score is only $4.5 \%$. The most difficult topic for the respondents (it got the lowest score) turned out to be calculation of the compound interest.

\section{Perceptions \& Financial Behavior}

The SSRUIC survey has assessed the perceptions of the SSRUIC students and alumni concerning their financial behavior overall and more specifically - about their saving plans, saving bank account, thinking before making purchases and satisfaction with spending money more than making savings for the future. Partial results are outlined below:

1. Saving Plan

A large percentage of the respondents indicated that they are saving money. When asked specifically how they set aside money for their savings, the majority $(70.7 \%)$ of the alumni and $45.3 \%$ of the students indicated that they paid their expenses first, before saving the rest. Fig. 1 below shows the distribution in more detail. 


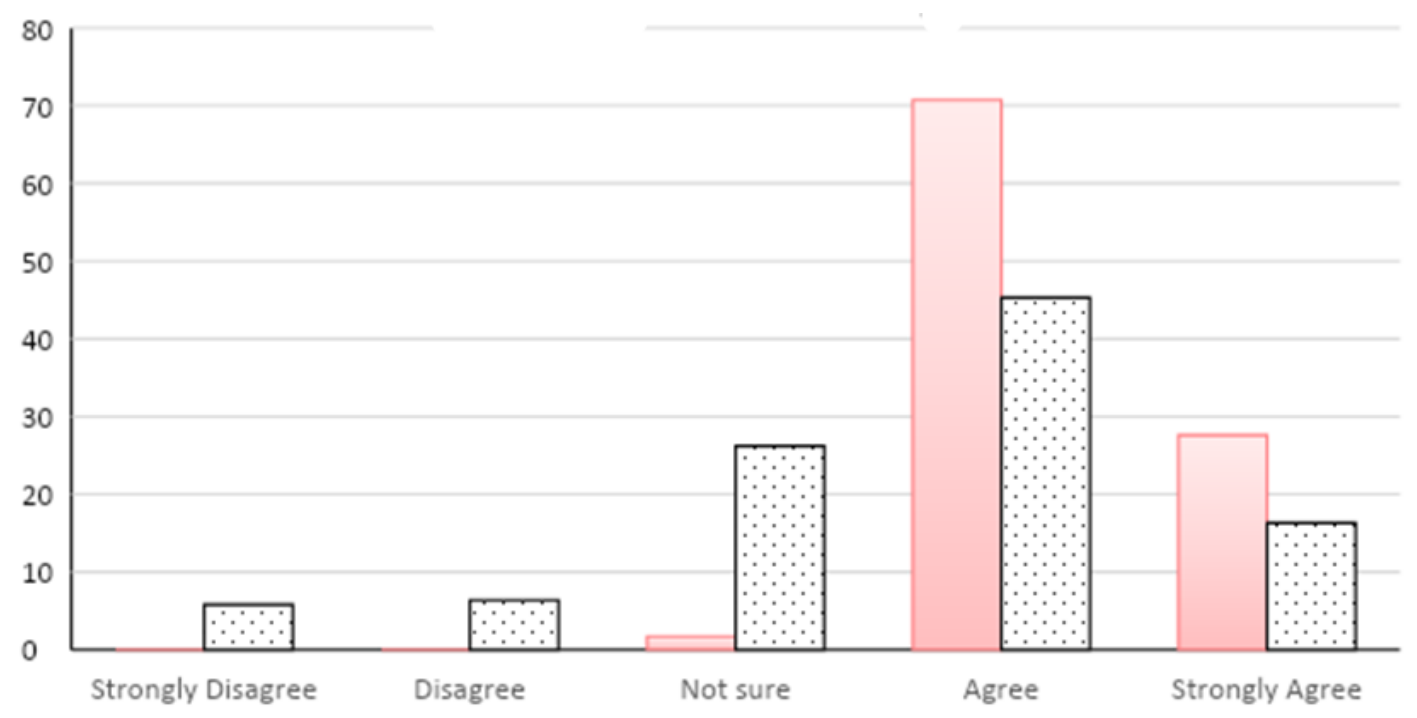

Figure 1 - Saving plans among students and alumni (made by author)

Among those respondents who put money on bank accounts, about half of the alumni indicated they had saving accounts in the same bank where they have their salary accounts. At the same time, $29 \%$ of the students indicated they had only one bank account.

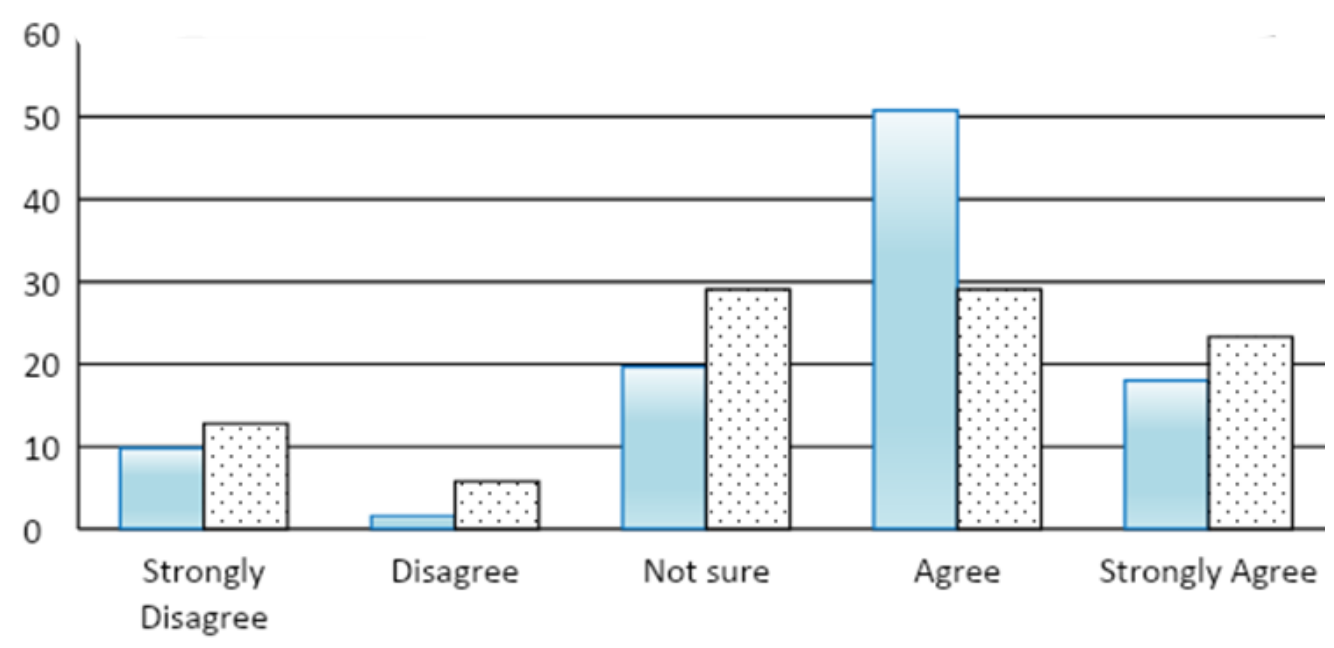

Figure 2 - Students' and alumni's answers regarding bank accounts (made by author)

2. Thinking before making a purchase

When asked about purchasing durable items, $50.8 \%$ of the alumni and $34.9 \%$ of the students indicated they are carefully thinking before making a purchase. They would not make a purchase if they could not afford the item. 


\section{FINANCIAL LITERACY, MATHEMATICS LITERACY}

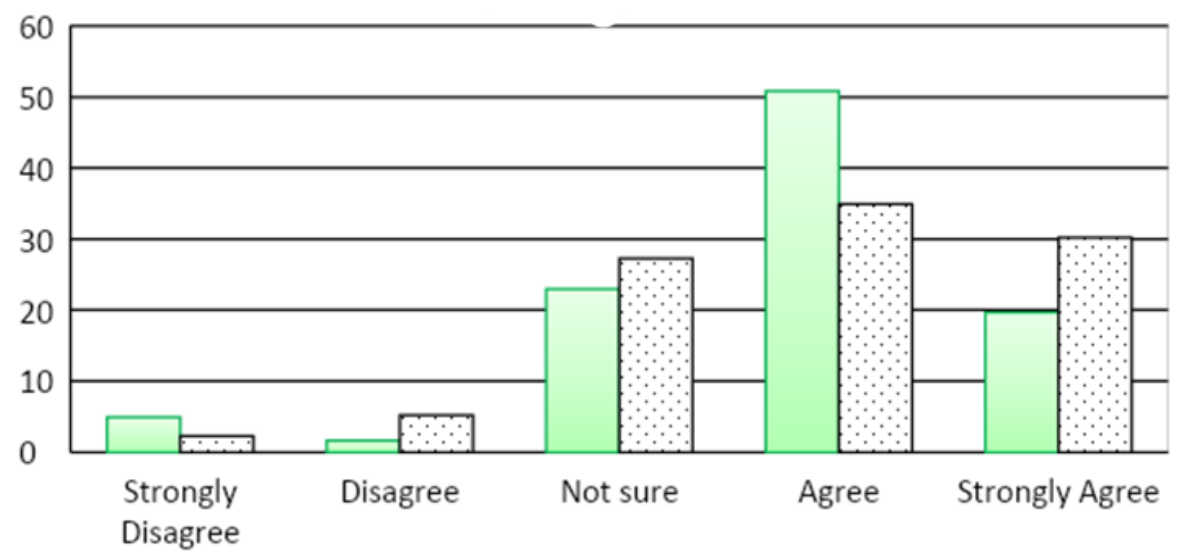

Figure 3 - Decision-making regarding serious purchases (made by author)

3. Spending more money than saving for the future

All the respondents were asked about their perceptions of saving money overall. $63.8 \%$ of the alumni and $26.3 \%$ of the students indicated they agree with the statement "I find it more satisfying to spend money than to save it for the future".

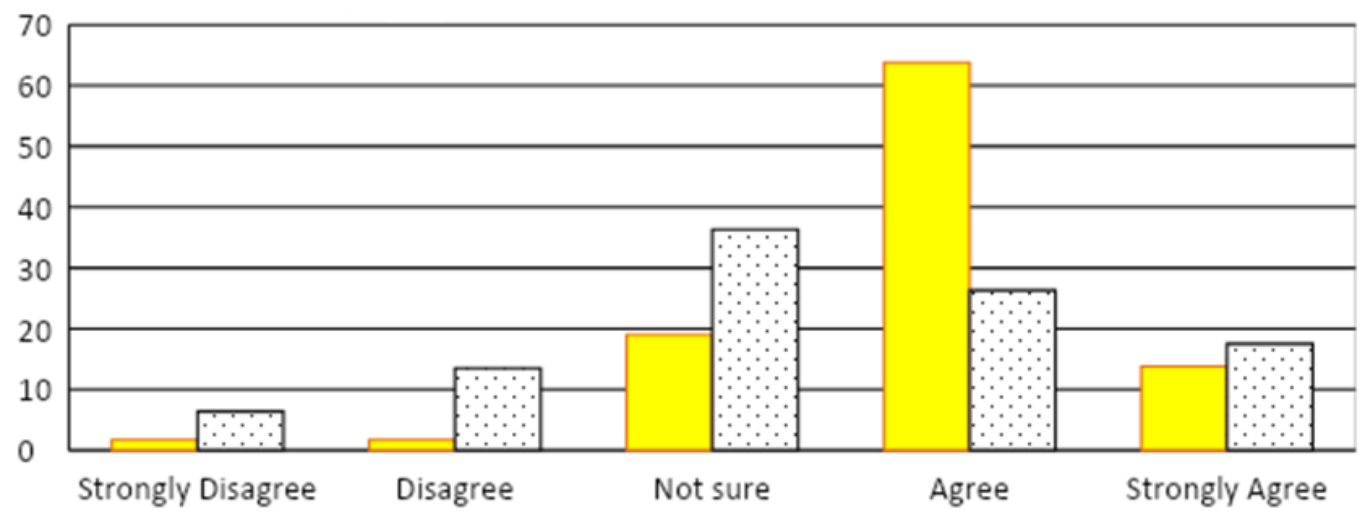

Figure 4 - Personal satisfaction with spending money rather than saving it for the future (made by author)

\section{Attitude to the use of fintech smartphone applications}

Our SSRUIC survey assessed the attitudes among students and alumni towards the use of fintech smartphone applications. The questionnaire was divided into five parts. These were: 1) the ability and limitations; 2) accuracy; 3) security; 4) convenience; and 5) worthiness of having such apps on a smartphone. The survey results are as follows:

1. Knowing about the capacities and limitations of fintech applications.

The findings show that SSRUIC alumni and students have different attitudes towards the use of fintech apps. Two-thirds of the alumni (or 68.4\%) agreed that they knew the ability 
and limitations of such applications, whereas only less than a half (47.9\%) of the students confirmed the same. Figure 5 below shows more details on this.

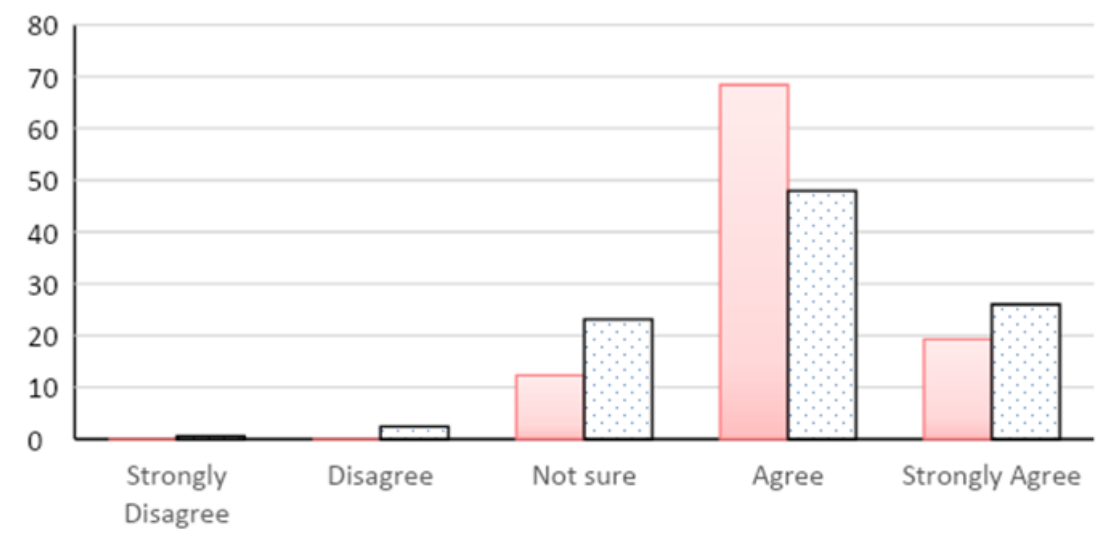

Figure 5 - Students' and alumni's perceptions about the knowing about abilities and limitations of fintech smartphone apps

(made by author)

2. Accuracy of fintech smartphone apps

Almost half of the alumni (or 49.1\%) and more than half of all the students (or 52.7\%) agreed on the accuracy of fintech smartphone apps. Fig. 6 below shows the percentage distribution of the respondents.

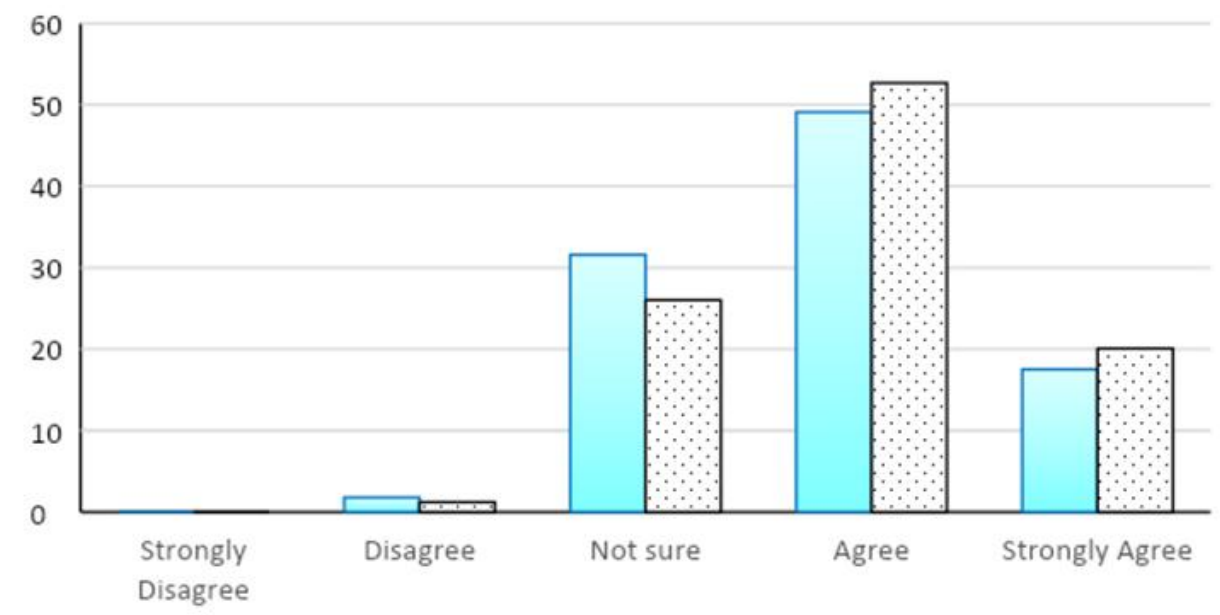

Figure 6 - Answers on the accuracy of fintech smartphone apps (made by author)

3. Security of using fintech applications

The findings show that $45.6 \%$ of the alumni and $50.3 \%$ of the students agreed on the security of using fintech applications via own smartphones. Such percentage of answers can be explained, at least, partially by the fact that there is sufficient evidence on how exactly 


\section{FINANCIAL LITERACY, MATHEMATICS LITERACY}

fintech mobile apps and the service systems of banks are connected. Fig. 7 below shows more details on the answers to this question.

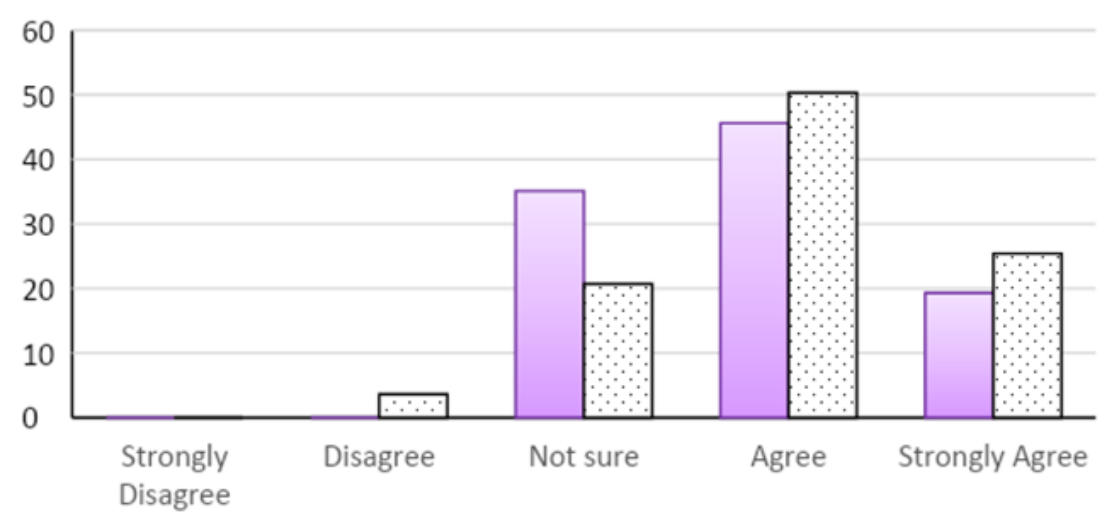

Figure 7 - Perceptions of fintech apps security in usage (made by author)

4. Convenience of using fintech applications

All the respondents were asked about the perception of using fintech applications on their smartphones. $50.9 \%$ of the alumni and $42.6 \%$ of the students agreed with the option "I always transfer money by using a fintech application".

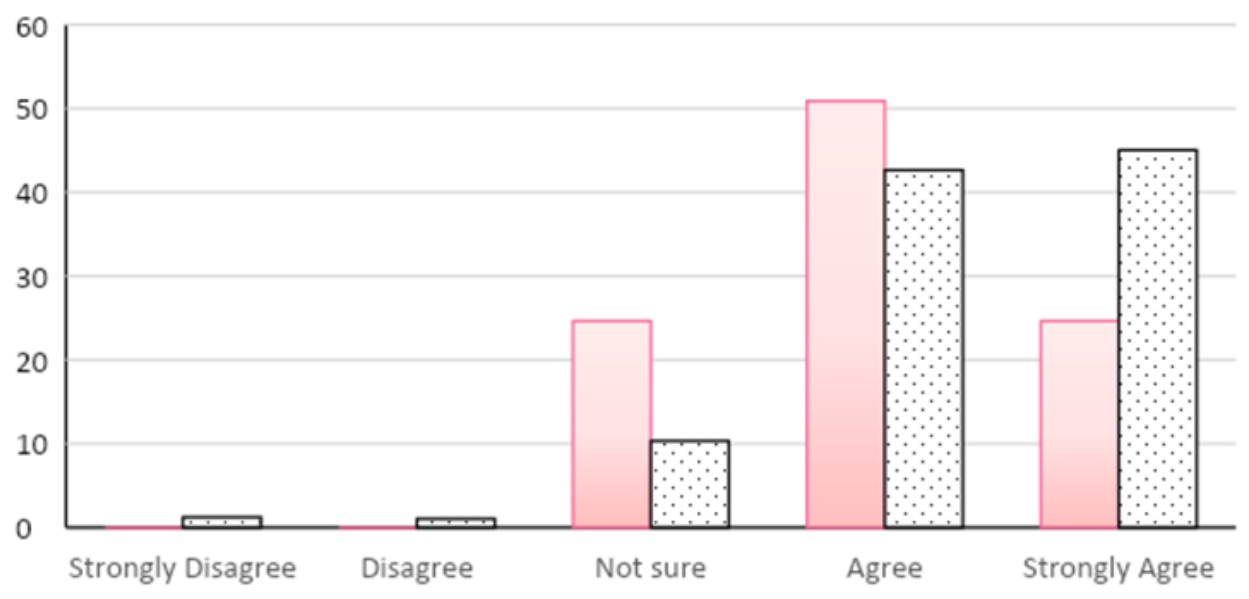

Figure 8 - Perceptions of convenience from using fintech applications in a smartphone (made by author)

5. Worthiness of using fintech applications

About half $(50.9 \%)$ of the alumni respondents indicated that they felt it was worth using fintech applications on their smartphones. The related fees have been assessed as being reasonable and acceptable. About one-third (37.9\%) of the student respondents agreed that it has been worthy of using fintech applications. 


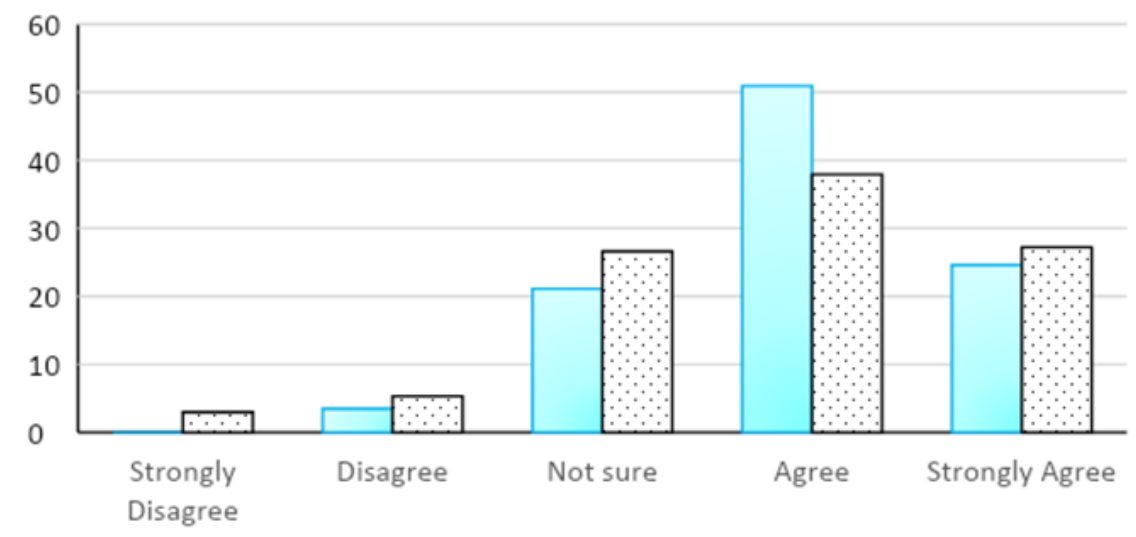

Figure 9 - Students' and alumni's perceptions of worthiness of using fintech applications (made by author)

\section{Conclusion}

The research findings have revealed that the attitude of students and alumni of the International College, Suan Sunandha Rajabhat University (Bangkok, Thailand) are not that much different. This is, most probably, because the sample overall belongs to the same Generation Y. This age group is using their smartphones all the time, therefore, they are very familiar with using many applications, including fintech ones.

The research findings can be used as a guideline while developing financial curriculum, in various educational innovations for teaching mathematics, in learning instructions and so on. Universities should be playing the key role in ensuring their students financially literate and well skilled. In today's world, everyone should have sufficient skills to manage their personal finances and money matters, regardless of the age.

\section{References:}

Atkinson, A. \& Messy, O. (2013). Promoting Financial Inclusion through Financial Education: OECD/INFE Evidence, Policies and Practice. OECD Working Papers on Finance, Insurance and Private Pensions, 34.

Bank of Thailand. (2013). Financial Literacy Survey Results.

Khairiree, K. (2018). Online and Mobile Learning Apps for Financial Literacy in Mathematics. The 2018 International Academic Research Conference in Lucerne, Switzerland.

OECD (2017). PISA 2015 Results (Volume IV) - Students' Financial Literacy. Retrieved from: www.oecd.org

OECD/INFE (2011). Measuring Financial Literacy: Core Questionnaire in Measuring Financial Literacy: Questionnaire and Guidance Notes for conducting an International Comparable Survey of Financial Literacy. Paris: OECD Retrieved from: http://www.oecd.org/finance/oecdinfe-survey.

OECD/INFE (2015). Toolkit for Measuring Financial Literacy and Financial Inclusion. http://www.oecd.org/daf/fin/financialeducation/2015_OECD_INFE_Toolkit_Measuring_Financial_L iteracy.pdf 


\section{FINANCIAL LITERACY, MATHEMATICS LITERACY}

OECD/INFE (2016). Organization for Economic Cooperation and Development: International Survey of Adult Financial Literacy Competencies. Retrieved from: http://www.oecd.org/finance/oecd-infe-survey-adult-financial-literacy-competencies.htm

Paper submitted

22 April 2020

Paper accepted for publishing

04 July 2020

Paper published online

31 July 2020 